\title{
Education in Pakistan: Perspective, Failures and Prospects
}

\author{
Ismail Saad *
}

\begin{abstract}
The basic assumption of this paper is that education, though the most enduring strand of the social fabric, must for clarity of understanding, be seen in the relevant political and economic contextual framework. The political and economic life in a country fosters and sustains education, but these forces are far too strong in impact and can very well work at cross purposes. The story of education in Pakistan that unfolded itself in a span of sixty years had its genesis in India and was a branching out from the same system which came as a legacy from the British. In Pakistan the system has grown and survived in a practically hostile political and economic environment. These conditions continue to stay on and education in the country is still hankering for a more hospitable climate.
\end{abstract}

Keywords: Education, Pakistan, political stability, economic environment.

\section{History as a Perspective:}

Before the coming of the British, Muslims, perhaps, as a group faired better in education and also recorded a better literacy rate. Any favorable or unfavorable comments, however, on mass literacy of that period can hardly be fair or cogent. Until the 18th century, awareness of the need of education had never seeped though the masses, nor was there any realization that it was needed by the bulk of the population or by each and every person.

Despite the fact that Muslims received guidance by the religious dictum that education was a duty, enjoined upon every man and woman, expectations about its implementation in letter and spirit was neither contextually relevant nor even desirable. The need for education, at the start, was propelled by the zeal of propagating religion and transforming it into a social force, which would bring consensus in the shared feelings of the community of converts to the new faith. Education, at that time, was practically divorced from its economic justification as a contributor to the growth and promotion of the process of economic production in a country, or to be able to participate as an imperative factor of production in the national economy.

This realization began to surface in the 18th century and since then it has never stopped gaining speed and acceleration. In the world today, we may talk idealistically about education highlighting religious, moral, patriotic needs but this would tantamount to camouflaging the basic fact that the desire for education today stems principally from the desire of economic gain and material development. The change in the direction of an economic perception came to the subcontinent in the wake of the coming of the Europeans to the

\footnotetext{
* Dean \& Professor, Faculty of Education \& Learning Sciences, IQRA University,

E-mail: drismailsaad@yahoo.com
} 
shores of India, eventually resulting in subjugation and establishment of a well entrenched government of the British in the subcontinent.

The conflict of interest between the Muslim community and the new rulers was inevitable. It is not only that the political power was wrested from the hands of the Muslims, even socially and culturally they had a bleak future staring in their face. The initial reaction was to deny the new realities altogether and withdraw into their own shells. But change eventually succeeds in getting itself accepted by those who did not like to believe it at first. In the sphere of education, there were two reactions, the traditional and the futuristic or modern. At the beginning the former was stronger and ruled supreme, but eventually had to give way to the wave of the days to come. The establishment of Deoband in 1865 was an educational effort to reassert the old order and to continue with the education, which was, as a legacy, part of the indigenous culture. The second reaction presented itself in the form of Muhammadan Anglo Oriental College at Aligarh in 1877. The difference in the two approaches was not only in educational form and content, but reflected a fundamental difference of outlook and perspective. The traditional approach adhered to the Islamic religious values in a cultural context relevant to the Asian continent in general and to Indian Persian and Arabic cultural scene in particular. On the intellectual level also, it reflected a heavy reliance on the revelation and logic as against empirically ascertained knowledge. The system of education based on the traditional premises is still with us but has lost its force and vitality.

The modern approach in the field of education was initiated by Sir Syed Ahmed Khan and his colleagues, which advocated a rapid adoption of the western cultural legacy, language, beliefs and practices. They realized that the balance of power was clearly in favor of the West and would continue to be so. The new realities were not an accident of history, but had a stable intellectual and material base, strengthened by the expanding field of scientific knowledge and the developing of new technologies. Sir Syed was firmly convinced that the reluctance of Muslims to accept and adopt the reality of new forces would lead them to utter destruction and cultural devastation. Both approaches had their strengths and flaws, but it was clear that the new direction was much more vigorous and dynamic, filled with vitality and hope for the future. It was the way and trend of the future. The new forces emanating in Europe had given the West a new strength and fresh vigor. The waters of European knowledge were being mingled with a new stream of empirical and experimental sciences. The interest in this world and in the smaller things of the earth was increasing, giving the western man a new confidence and belief in his capabilities. The scene was different in eastern countries. They had possibly a mature civilization, but it was weakening from within. The vitality, once experienced by them, had lost its force and their interest in the world had taken a passive character. The center of gravity had shifted from the East to the West and the winds coming from the West were blowing in the direction of the East. The times were ripe for the coming of the Europeans to the subcontinent and culminated in the establishment of a stable British rule in what was then India. The way of life and the many related things that the British brought with them, also included a new and different pattern of education, which became a fascination to Sir Syed Ahmed Khan. The education introduced by the British had a definite economic objective as it kept the main purpose of earning a living in the forefront. The British type of education was tied 
up with economic privileges, financial benefits and material well being and progress which worked as an incentive. No one can for very long, close their eyes to economic realities and allurements and that must be the reason for the majority community in the subcontinent to grab the opportunity of improving and bettering their lives.

Muslims were slow in clearly realizing the opportunity of worldly benefits and it was with some reticence that a very small segment of the Muslim population grasped the changed situation and turned in the direction of western education. The growing feeling of competition with the major community must also have served as an impelling force. In this initial stage they had their share of difficulties presented to them by the bulk of their own Muslim community, but they patiently continued with it, knowing well that the future was with them. Though education today looks tied up with the notion and concept of democracy and egalitarian values, it was not so, to begin with.

The new education made a show of disseminating new ideas, new sciences, new values a new way of life, but the mission was not all that simple. The system of education in the West, in European countries and in England was not exactly the same as was transported to the subcontinent. The objectives of a new system of education in India were not principally educational, but political and economic. It was not meant principally to cater the needs of the people in India, but to the purposes of the British. The need of the new rulers was an effective and strong government, which could provide a stable base to their political ambitions. For this purpose the primary need was a well organized bureaucratic setup with a tapering power structure from top to bottom. The British urgently needed a workforce functioning at different levels of administrative machinery with a proper chain of command. It was natural that in this structural pyramid, the natives or Indians would hang about at the lower rungs of the administrative ladder and in the same manner the wealth, power and prestige to be disbursed would also be distributed. The need of good governance favors the division of the workforce in classes, though on the surface they appear interacting with each other for a common purpose, persistent class feeling, at the same time, nurtures hostility between and among them. The Indian subjects accepted the administrative structure as a matter of course as they were already accustomed to a rigid caste and class system, supported and reinforced by religious conviction. The British though, expected to be egalitarian in outlook, had also then a class system as their own way of life. In the context of India, it was inevitably also a political need to keep the rulers separate and at a distance from the ruled. Even the Indian co-workers in the British administrative setup were kept apart from the real masters. This was, possibly, the only way of ruling the country effectively and to fulfill their needs and objectives of governing a foreign country. It was imperative at the time to work and use education primarily for reinforcing and strengthening a stable British rule in India. The economic returns, privileges, rewards and gains were the motivating force, which drove the Indian population, Hindus and Muslims alike, in the direction of new education.

Thus the system of education, which came to India, had problems and a basic contradiction within. It was an instrument of purposes, which were not educational but principally political, and could not possibly cater to or satisfy the educational needs of the people of India. The subcontinent then at a low level of technical and scientific development needed the intellectual, emotional and physical growth of its people. It needed the spread of new 
knowledge; new technology to build up an infrastructure, a new economic and industrial organization, but the system of education in India was not up to the challenge. It could, at best, contribute accidentally, or peripherally to the developmental needs of the people and any expectations over and above were beyond the scope and power of the new system of education. In the succeeding 100 years or so of stable British rule, not necessarily by design, but by the force of events, the system of education developed both in size and in quality. Educationally desirable purposes, introduction of new sciences, new values, new technology and new modes of thinking were the incidental and fringe benefits and contributed to the cultural richness of Indian society. However, the contradictions and ambivalences persisted and continued making a problematical situation even more complex. The salient contradiction was abetting a class hostility, as against an almost proclaimed goal of civilizing the natives in new values imbued with egalitarian and democratic spirit. Many complications arose. The system of education in India perpetuated a stratified class system and divided education on lines of power, prestige and wealth enjoyed by different segments of population. The second thing was subjugation of educational purposes by the colonial ends and political objectives. The third drawback was a weak relationship of education with economy. Another weakness was a trend of cultural alienation underscoring an educational cleavage between the Indian and western culture. Other causes included a very slow increase of educational opportunity and a very low level of the quality of education.

Native responses to the changed educational situation were many and diverse. There were conservative responses, both among Hindus and Muslims. The Muslim conservative response concentrated on longing and lamenting about the decline of old traditions and values; religious debilitation and a cultural onslaught from the west. The other more organized responses were in the form of educational movements, like Kashi Vidya Pate, Banaras Hindu University Shanti Niketan and a chain of D.A.V. (Dayananda Anglo-Vedic) institutions. Among the Muslim, Jamia Millia Islamia, Anjuman Himayat-e-Islam sponsored institutions and Sind Madresatul Islam and various other endeavors in the field of education. There were other responses, social or individual, principally those motivated by politicians like Gokhale, Mohammad Ali Jinnah, Tilak, Lajpat Rai, Rabindra Nath Tagore, Maulana Mohammad Ali Johar, Gandhi and others. They were mainly interested in the democratic values and the benefits of education within the framework of a western perspective, they expressed interest in the expansion of educational opportunity in India, in expressing the need of economically more valuable education for national development. Their endeavors contributed to the political integration of the country through education and the building of human resource and economic infrastructure for economic development. These leaders were not in a position to build up a system of education according to their hearts' desire in tangible and concrete form, but they did what was possible for them to do, namely, discussing educational issues and criticizing the British educational effort and policy. At times an educational controversy raged even among Indians themselves in an ethnic, social, communal or political context, for instance, the educational perceptions of Hindus and Muslims differed and continued to be increasingly divergent during the days to come. The educational situation continued more or less in the same fluid manner till the creation of Pakistan in 1947. 


\section{The Ferment of Separation}

The creation of Pakistan in 1947 was a somewhat dramatic event. This is not to say that Pakistan came into being because of a sudden situational change in the Indian body politic. The seeds of the Pakistan Movement were simmering and fermenting for a very long time, some would say, almost as long as 1300 years, when the first group of Muslims stepped in the territory we know today as the subcontinent. Interaction and assimilation of migrating populations with the settled population of the land, is always a difficult process. But in case of Muslims it proved even more difficult. The differences were not only important but also inflammable. Monotheism, or the belief in one God, is the basic tenet of Islam on which it accommodates no compromise. As against this the Hindu beliefs in one or many gods varying from one group of devotees to another could not be palatable or reconciled by the Muslims who would always remain a minority with power and authority in the new land. Muslims were not welcomed or accepted by the Indian population but they imposed themselves on them for the sheer reason that they were at that period of history in possession of greater military skills, a more dynamic technology and a reservoir of knowledge, more practical in its impact. In the long span of Muslim rule a process of assimilation and cultural interchange also continued but it was a weaker force than the political instruments of reward and punishment, which could be employed by the dominant group. The Muslims managed political stability because they possessed political power to govern the Indian subjects. The ever-present hostility between the two communities could, if exploited by the vested interests, erupt in open conflict, but during the long Muslim period, it remained subterranean taking the form of an uneasy compromise. The situation changed dramatically when the British entered the scene and established their own government in India. It was now Muslims who were at the receiving end and they experienced the greater setback and trauma of their political and cultural life. The emotional reaction in a pent up form would change the course and in the long run flow in the direction of and against the majority community. It was the communal hostility and the consequent inability to workout a modus vivendi with the majority community which led the Muslim population in the direction of the demand for Pakistan and the Pakistan Movement. There were many variables and factors, which contributed to the acceleration of the movement, which included the perceived excesses of the majority community and the feelings of humiliation and insecurity by the Muslims as documented in the Pirpur Report (1928).

The reservoir of emotional energy and the unique personal and cultural characteristics of the Muslims to build up an emotional consensus at the spur of the moment also played an important part in giving a force and dynamism to the demand of a new country. What, however, must be noted, is that education also played a significant part in mobilizing and organizing and building up a consensus which would work as an inner force for the Pakistan Movement. The Aligarh Muslim University and the graduating students worked significantly in propelling the Muslim consciousness and in contributing maturity to its form. 


\section{Education in the New Country}

Education in Pakistan started with a scanty baggage. The system, the structure and the physical paraphernalia was the same as in India, but at a much smaller scale, for Pakistan was not only almost one fourth of India in size but the availability of schools and other educational infrastructure were in comparison even smaller than the size of the territory. There was a sudden attrition of teachers for teaching staff belonging to the Hindu community schools left enmasse from West Pakistan and migrated to India. The Muslim migrants coming from India, though provided a good number of teachers, but the total number of teachers available was highly inadequate. In fact if we try to look at the situation from the human resource point of view, Pakistan suffered adversely in the needed manpower and as a new country experienced a setback. The overall picture showed a highly inadequate number of skilled and white-collar workers, doctors, engineers, teachers, lawyers, bankers and other professionals. For offices and administrative setups, the human resource consisted of civil servants and other office workers at lower levels. These people were trained as competent bureaucrats but their efficiency and skills did not necessarily imply a motivation or devotion to the country. Before the creation of Pakistan, the civil servants exhibited a high level of motivation and commitment to Pakistan, which continued during the initial years of Pakistan, but then gradually the spirit dried up when the threat and challenge of the majority community subsided.

The creation of Pakistan also offered a challenge and growth is very important for the Pakistan (Qazi, Raza, \& Jawaid, 2014), for the task was to build a new country, desperately in need of overall development. The challenge was even more formidable in the sphere of education for the country needed not only human resource in the form of a sizeable workforce but also an avowed political commitment to expand educational opportunity to every child born in the country. The commitment was made by no less a personality than the founding father of the new country, Quaid-e-Azam Mohammad Ali Jinnah.

Quaid-e-Azam's interest in education was well known. His first speech in the Imperial Legislative Assembly in 1910 was on compulsory primary education - which still remains a dream for Pakistan as a whole. He not only had great love for students, motivated and guided them for political struggle, but he was greatly concerned about their schooling and need of serious study. His interest in education stemmed from a liberal attitude of mind and a fervor for democracy and democratic ideals. Even in days when he was a member of the Indian National Congress, he repeatedly made long passionate but logical speeches in the Central Assembly about primary education and the right of every child to have access to education. He was at that time a lieutenant and co-associate of Gokhle and both of them together, in addition to their political interest, tried to work for the cause of education. Education was so much on his mind that immediately after the inception of Pakistan, he directed the holding of a national conference on education, which was actually held from November 27 to December 1, 1947. This concern for education does not go in line with the initial attention given to education by the first government of Pakistan, which did not have even an Education Ministry. The Education Division was a part of the Ministry of Interior; education was treated as an additional charge.

The first educational conference was held on November 27, 1947. Quaid-e-Azam Mo- 
hammad Ali Jinnah, due to health reasons, could not attend the meeting but sent a message, which reflected not only his deep and practical understanding of education but also an open-minded, liberal, democratic, and scientific frame of mind. The message envisaged a Muslim but pluralistic society, where diverse other groups will live in an interactive cooperative relationship with the majority community in peace and harmony. Education, which would be the right of every citizen, would serve as the propelling force of a culturally assimilating forward-looking society. He placed emphasis on the expansion of educational opportunity, of education interfacing with the Islamic legacy and the cultural genius of the country. The need of scientific and technical human resource to be aligned with the demands of a developing economy and the inculcation of values suited to a progressive society marching forward with an international outlook. The theme put forward by the founding leader served as the blueprint of the conference agenda. The striking feature of this first important congregation was that it had representatives from all communities and classes, and they all made an earnest effort to develop a consensus in formulating policy guidelines for the first educational policy of the new country. The direction of the policy was pointed toward the masses and for the expansion of the educational opportunity as rapidly as possible. The ratio of literacy in the country in 1947, was $15.1 \%$ and the intention was expressed to bring it to the level of $100 \%$ literate population, and free and universal primary education. Educational action and transformation was to be carried out within the then existing instructional pattern of what can be said, the beginning of a system of education. The policy and action plan which was discussed covered all the levels of education and keeping in view the limitations of the system inherited, guidelines for further movement and changes were put forward. The politicians and leaders of the country were to announce the first blueprint of educational progress and they wanted to map out a popular system, which would cater to the educational needs with a very broad base covering the entire expanse from the grass-root level onwards. A striking feature of the incipient system of education would be an identity with the indigenous culture and social values, Islamic outlook, a thrust in the direction of science and technology, keeping pace with the expanding frontiers of knowledge and, last but not the least, the process of national integration and cultivation of patriotism, emanating from the concept of unity in diversity. There were limitations and difficulties also in the way. The country had to move forward with scant resources, there were initial calamities of exodus and migration of population, lack of infrastructure, absence of administrative machinery and an industrial base and a highly deficient reservoir of human resource. These problems posed staggering difficulties in the way of implementation. The administrative machinery, which was expected to launch and implement the educational guidelines, was half-hearted as they lacked motivation. The training of civil service had not given them the know-how and experience of dealing with issues and problems facing the people at the grass-root level. Their approach was not of service and servants, but of rulers and governors who could not come out of their cozy and comfortable compartments into the open. The politicians of the initial lot had the motivation and zeal to transform the new county according to their hearts' desire but they had to heavily rely upon the civil servants and bureaucrats, who were a class of vested interests, much more stable than the leaders and politicians in the country. There was increasing disarray in the ranks, which brought growing instability, not 
only among the politicians, but the whole body politic. The result was that the educational blueprint remained only on paper and could not be implemented. It was after a gap of three years that an action plan was formulated, but by the time political instability had gone beyond proportion, too shaky to be able to take any meaningful educational steps. At this early stage the educational plan was not aligned or integrated with the economic plan and, therefore, it was practically divorced from financial resources, which could have given the educational map a concrete form and structure.

In the political life of the country, the first clash and conflict started between the first generation of politicians and bureaucracy which had, by now, mobilized itself as a stable force. In the oncoming fight the first victim was Shaheed Liaquat Ali Khan who had at least given a semblance of stability to political government. From the death of Liaquat Ali Khan in 1951, bureaucracy gained the upper hand in running the country and its politics. The political governments were there but their role was no better than the game of musical chairs where, one after the other, the political governments made an exit. Even during this span, the top political seat of President of the country was occupied by the bureaucrats. Any expectation that they as bureaucracy would give any meaningful or dynamic steering to the need and cause of education in the country could only be a futile hope. The period came to an end in 1958 when the first Army Chief made a claim to power. The claim was understandable in the sense that he represented the source of power and the real position of the bureaucrats could not be better than that of the hanger-ons. The first long and stable span of political stability stretches from 1958 to 1969, when Ayub Khan was the unchallenged political ruler of the country. No doubt, the legitimacy of Ayub's power could be questioned as it was thwarting the democratic process in the country, but it was accepted and initially welcomed by the people because of the turbulent situation of the country. When Pakistan came into being as a country, it had a premature cesarean birth, and the newborn carried many odd features. The country was a political oddity, a geographical oddity, an economic oddity, a socio-religious oddity and a combination of other minor oddities. During the initial phase of the great upheaval, combined with the surge of patriotic fervor, the oddities did not appear as alarming, but with the passage of time, they were bound to show strain and emerge as serious and formidable problematic issues. One advantage of the martial law and the subsequent military government could be the possibility of effective and strong political decisions needed for rapid development. The efficiency could be further reinforced through a working combination of the bureaucracy and the armed services. The well-trained bureaucratic personnel could not only prepare strategies, plans and policies, but they could also effectively implement them. In this respect, democratic governments are always handicapped and have to work in a weak position. A commission was constituted by President Ayub Khan to formulate an education policy and with the expected efficiency and speed, its Report was announced in 1959, and is known as Report of the Commission on National Education. This was a very comprehensive document, encompassing all the different features of a good forward-looking educational system. For every stage and area of education micro type approach was adopted to work out the details. The report was comparable to any educational policy document of a developed country. Setting up of targets and planned action was proposed and the objectivity of measures planned impressed the reader. However, any hope that the policy would get the 
ball rolling in the educational sphere and would gain momentum with the passing of time could only be optimistic and fanciful. The causes of failure were many, only the important among these can be highlighted. The paucity of resources, allocated to the education sector was the primary handicap, which could rank education no better than a low priority area in the list of national objectives.

Despite education being a concurrent subject, a strong centralized government did not allow the provincial governments to freely develop educational paraphernalia. An increasingly centralized control of education was interpreted as an attempt to discipline and subdue, politically the most turbulent segment of population comprising of students and teachers. The structural change in the education setup and expectations of a trouble-free environment was naive and failed to bear fruit. Weak motivation of bureaucracy to place emphasis on educational development and the preservation of a stratified educational system proved to be the main handicapping causes. Negative and belligerent reactions by students and teachers erupted and when force failed to work, a National Commission on Student Problems and Welfare was constituted under the chairmanship of Mr. Justice Hamoodur Rahman, a Judge of the Supreme Court of Pakistan but that also proved a failure and some of the major recommendations of policy document had to be withdrawn. The policy, on the whole, cannot be rated as a complete failure and might have even contributed to giving education in the country a sense of direction. A noticeable achievement was that, an attempt was made for the first time to relate education to the national economy and to produce manpower to enhance the human resource in the country. Structurally however, no significant change could be introduced and the inverted pyramid of educational structure, with a narrow base on the ground and a wide base at the top continued. This meant that excessive attention and resources were to be spent on higher education, which was the stage from where ready manpower could enter the economy and job market. However, the historical neglect of primary education continued and perpetuated at the base. This further inhibited the democratization of society and discouraged egalitarian tendencies in the social life. On the whole the negative aspects of the policy outweighed the positive features.

The political transition brought General Yahya to power, which in a way, was a continuation of the military regime. It culminated in the tragic debacle of eventual cessation of East Pakistan after a bitter civil war aided by the neighboring country along with Pakistan's third war with India in Nov-Dec 1971. From the point of view of education the stance of the Yahya government was that of a neutral operator. Education in 1969, a New Educational Policy was pronounced, which was authored by Air Marshal Nur Khan. It was even a better document than the 1959 policy, for it addressed the issue of providing a popular base to the educational activity and declared intention to attend to such critically important issues as the cleavage between the traditional Madressa and the mainstream education. The policy, however, failed to see the light of the day and was never implemented. The period, which followed General Yahya, was the most dramatic in the political history of the new country. The country did not only see the amputation of its far-flung eastern wing but experienced a shake up, if not a change, in its sociological make up. Until now the Pakistani society was divided into three classes a very small privileged class of vested interests at the top with business families, bureaucrats, army personnel, politicians, landed 
aristocracy. A small middle class with a larger lower middle section, touching the majority of low and poor people, this class of have-nots was neither educated nor in any way resourceful except their numbers to mobilize itself as an overwhelmingly powerful factor capable of causing law and order problem.

The next outstanding leader was Zulfiqar Ali Bhutto, a representative of the landed vested interest, but a man educated in the west and exposed to radical ideas of the left and of social change. Bhutto was a politician to the core. He looked at the class structure and was fascinated by the power, which potentially the lowest class of have-nots had and which he could muster and use to his advantage. He was also aware of the geographic, ethnic and cultural divide of the geographical regions of the country and could see the potential of political manipulation in his favor. The revolutionary ideas of the left had also a fascination for him and he knew that the situation was ripe where he could use these ideas to coin and frame political slogans and mobilize the poor of the country into a force to be reckoned with. The new political party he headed was named Pakistan Peoples' Party and its rallying cry was 'Roti, Kapra aur Makan'. Vigorous campaigning of the party and its program succeeded much beyond expectations and in West Pakistan the Peoples' Party carried overwhelmingly the mandate of the people. As against this, in East Pakistan, the Awami Party of Sheikh Mujibur Rahman emerged as almost the single majority party and the logical result of this pattern of electoral victories was the split of Pakistan into Bangladesh and Pakistan.

Bhutto had adopted and declared a socialist program as his political agenda and nationalization of the infrastructure and principal means of production were activated. Education could also not remain impervious to the drive for nationalization. On the surface this impressed as a dramatic shift in educational activity for it promised educational opportunity to every individual and every child free education, and made the government wholly responsible for education in the country. Private schools and educational institutions, mostly in cities, were nationalized and the system of education became a national enterprise. However, the glimmer was short lived. The system could not work. The resources required for an endeavor like this could never be mobilized by the country or the government. The decision to nationalize educational institutions, though consistent with the overall political policy and program, was taken at the spur of the moment and under immediate political pressure of teachers, with very little time to adequately prepare for such a formidable undertaking. Overnight all the private educational institutions in the country were nationalized but without a national policy as to run the system and without a long-term course of action.

With the benefit of hindsight, it can be said that as a policy action the nationalization of education was a tragic and ill-advised step taken. The drawbacks of the nationalization policy were many. In the first place, it disturbed and discouraged private initiative in the field of education. In a democratic setup, both public and private initiative work together and complement each other's efforts. No doubt, the public sector in Pakistan as the largest stakeholder had not only the resources and power to run and further promote its educational program and activity but also control and supervise the entire system of education, which also included the private sector education.

The justification of private education is that it supplements and increases the education 
sector activity. Furthermore, it expresses an increasing demand for quality in education, it offers parents an educational option for their children to pay for what they deem to be quality education. This is the democratic practice in countries committed to the democratic political process and should have been allowed to continue also in Pakistan. In fact, since the days of the British until 1972 a more helpful tradition had developed, and that was the government and private sector partnership where educational work was carried out by the public spirited private parties and government which worked as a healthy practice. Though an increasing amount of educational malpractices permitted by the private sector became the immediate cause for the decision to nationalize institutions, this was done irrespective of a distinction between commercially motivated institutions and otherwise. Commercially motivated institutions, though undesirable, still contribute to the increase in the expansion of educational opportunity as they allow parents to exert a free choice to decide about the educational provision of their children. In the wholesale nationalization of educational institutions of the country there was no consistency either. Not much later, those institutions were denationalized which charged higher fees. On the surface this decision may impress as well intended, but in reality this was discriminating to the poor and was an attempt to perpetuate the class structure in the society which meant that the poor quality and namesake education would be the share of the poor and the rich could partake of the quality education and thus continue with their green islands of prosperity in the midst of appalling poverty. As expected education suffered a serious setback in terms of quality and contributed practically nothing to personality development of individual student or in building up valuable human resource for the country. The meteoric rise of Bhutto came to an end when he was ousted by General Zia-ul-Haque, another army stalwart in 1977. The transition had strange features, potentially the new successor had an unexpected high political caliber. He was cunningly shrewd, and stranger than fiction, was chosen by Zulfiqar Ali Bhutto, himself. As the events proved, the choice was a folly, for Zia-ul-Haque, simply managed to allure Bhutto in a trap duped by his deceptive simplicity.

General Zia-ul-Haque survived the next ten years and had time to implement a stable rule. What Bhutto somewhat belatedly realized became a strong point of General Zia. During the period of Peoples Party, Bhutto had begun to realize the political importance of the religiously oriented conservative lobby. He had to make perforce several decisions to please the religious groups, but the action was perhaps too late. Zia-ul-Haque was perceptive enough to grasp and understand the importance of religious groups. Bhutto considered the popular base as the only source of power, but did not clearly understand the political importance of religious leaders and scholars as a pressure group, as they were never a group who could win votes and the small count they could manage was too weak to make a difference. Internationally, he understood the importance of Muslim population and the Islamic countries as a political force, specially, following the windfall of black gold. But at home he was touching the edge of over confidence in thinking that he could manage and fix anything. Zia-ul-Haque, despite his initial shortcomings and drawbacks, was never arrogantly proud or confident to the extent of making this personal trait a weakness. He was deceptively unassuming and avoided annoying anyone. With his focus on the Islamic lobby he decided and planned to make use of the religious character of Pakistan as an instrument of political policy and launched his program of Islamization of the society. The bogey 
of Islamization was bound to make entry into field of education. The educational policy, announced by Zia-ul-Haque, though did not touch the core issue, tried to give a different look to the system of education. He brought the outward trappings and decorations of Islam to the prevailing system. In an attempt to compare the two policies, sponsored by Bhutto and Zia-ul-Haque sequentially, we will not find any meaningful or significant deviation, except the camouflaging orientation of the left and the right. Education was still a low priority, no additional funds were committed, and no basic structural changes were introduced. The only meaningful step in the later policy was a cajoling overture in the direction of Madressa education to please the Madressa system and to receive the best wishes of the rest of the Muslim world, specially, the newly rich affluent Muslim countries. Internally such a step was long overdue in the educational field, for two parallel educational systems were operating in the country, almost hostile to each other, with no serious effort to bring them together. It was Zia-ul-Haque's singular contribution to treat the votaries of the religious system of education with respect and allow them a suitable place and status in the mainstream of Pakistani life and education. The policy appears also an attempt to bring education nearer to the indigenous life and culture. British education in the subcontinent had alienated itself in its own cultural matrix and because of the vested interest of bureaucracy; the alienation persisted and is still existing and effective. The span of Zia-ul-Haque's rule represents a short lived deviation from the established educational norm. He tried to give education a cultural and religious identity and though it was short lived, it has had its impact at least in pointing out the need of giving education a native and indigenous form and character. The language issue can be taken as a case in point. Zia-ulHaque announced Urdu and the indigenous languages as the mediums of instruction. This was a radical departure and did not suit or please the vested interests in the country who were the votaries of a class based elitist approach to education. Zia-ul-Haque must have realized that he had overstepped his limits, for he could not survive politically without their support and eventually and perhaps with some reluctance, the announced policy was taken back. The previous regimes, including that of Bhutto talked about national and indigenous languages but chose to place added emphasis on the importance of English language as the medium of instruction as it was not only a matter of habit with the educated and privileged class, but was also consistent with the new forces of market economy. Soon the deviant behavior of Zia-ul-Haque became apparent as an aberration and the supremacy of the English language in the country in general and the field of education in particular, reasserted itself with added vigor and established its unchallenged sway.

The aftermath of Zia-ul-Haque for a period of about 11 years, touching the new century, saw four governments with two leaders and two parties. With the accidental death of Ziaul-Haque, the army rule ended and the period of parliamentary democracy started the journey again. The period also saw almost three new education policies, every change in the government warranted a new policy as the custom had been in Pakistan. Since there was no qualitative change in the four governments, they can be summed up as a single phase. This time it was not a planned struggle, which had culminated in a shift to democracy. The world political climate and environment was becoming increasingly favorable to the western pattern of democracy, the military regimes and army governments were becoming out of fashion and as the general psychology of the people does not favor a single government for 
an extended length of time, the situation and circumstances warranted a political change and a new government.

The army itself was weary, not of the long duration but the growing unpopularity in the country as a whole and in the urban territory and population in particular. When Benazir Bhutto took power in her hand, it was given to her on a silver platter by the army. It was on the face of it a very wise and large-hearted gesture by the army. The appearances can also be deceiving. In the background army never had any intention of handing over the power or to allow a perfectly free hand to democratic upstarts. The army was interested in the power from the very beginning but by now, it had established a permanent vested interest. The army was the most stable and organized structural organization in the country and had still, as compared to others, a good reputation in the country and among the people. The new and young leaders of the country needed to realize this established ground reality and should have devised a way for power sharing but the enthusiasm of the young is too fervent and volatile to agree to or reconcile with stark realities and this was bound to generate trouble for the two leaders and the renewed democratic experiment.

Education, during this period, received attention but remained at the same tempo as was the custom during the previous regimes. No change was initiated in the structural form or content and education continued to stay at the same level in the list of national priorities. Verbal claims and talks abounded but no serious intentions of making the promises true or practically implementing new schemes and policies were visible. Corruption in the country touched a dramatic height and increased to a point where the world aid and loan giving agencies strengthened their grip and began to play an effective role in directing the internal affairs of the country. The impact of market economy and forces of globalization began to surface and the developing countries started feeling the pressure. Interest in futurism, rapid social and technological change and adjustment with it also became a need and reality.

Another impelling force was the coming of the 21st century, which stimulated the countries with retarded progress to see the event as a challenge and make up for the lost time. The internal situation in the aftermath of the Afghan war was like a festering wound with drug addiction, alarmingly increased access to weapons and firearms, the accompanying lawlessness and violence were steadily becoming a part of the culture and everyday life. The ethnic and sectarian divide made the situation even worse. Education could not remain impervious to all these factors and changed and transformed its features under the impact. The technological change introduced computers and electronic media in the educational institutions, the educational policy parameters were discussed, advised and directed in a greater degree by foreign and donor agencies. Though the subsidy received from these organizations increased, the aid agencies came into a position to determine and set the channels in which the finances and cash would flow. Lack of trust in government schemes encouraged the donor agencies to establish contacts with the private sector, specially, NGOs. The educational scene began rapidly to change, priorities were reestablished, up till now higher education was in the top list of the education priorities. But now for the first time from the mid 80s primary education began to receive increasing attention. It seems that the foreign aid advisors had decided to overturn the educational pyramid, allow primary education a wider base and prove that it was economically more productive and capable of giving better and much larger returns for any investment made in the education sector. 
With all this, however, the changes in the overall educational planning and administration also occurred, which meant that the monopoly of the government lost its grip and began to loosen and surrender it to the donor agencies and the private sector.

Pakistan entered the new century with excitement, but it would be too much to say that the country had braced itself and was ready to face the new challenges. The manner in which the process of educational activity unfolded itself in Pakistan at the turn of the century was a story of achievements and failures. In quantitative terms education did achieve and made significant strides but the expansion was more than offset by the population growth. The country with political hiccups trying to pickup speed but it could never catch up with the grim educational challenge confronting it. At the beginning of Pakistan including the then East Pakistan the literacy rate was 15.1 percent. The educational infrastructure comprised around 10,000 primary and middle schools (1700 for girls) with an enrollment of one million (including 130,000 girls). At the turn of the century to be precise in 1995, the comparative position had been 12 million for the primary secondary level students. The literacy rate according to 1998 census was $46 \%$ much less than the Bangladesh figure for the same period.

The pace of educational progress and expansion was uniformly slow as compared to other developing countries of the same rank, and Pakistan was not only way behind but the distance was increasing and growing day by day. The minimum $4 \%$ of the GNP which was advised by UNESCO, almost 50 years ago, was still an unachievable target for Pakistan and the country had not been able to reach even the $2 \%$ mark. There were a number of things noticeable about the structural form. The process of transformation and changing shape of the educational system, which can give us total vision of the educational scene in the country, was still in flux. The structural form of education, as introduced by the British, was more or less in place and continued to process the raw human material in the same manner as when the process was started. The system structurally had three levels of education - primary, secondary and higher education with universities at the top. Despite the expansion and branching out of the departments and curricular programs, the basic patterns remained essentially the same, with similar curricular provisions and teaching pattern. The assessment system based on an external examination system, except smaller or insignificant changes, kept its form and was still, like the old man of the sea, clung to and riding over the neck of the education system. The provision and ratio of educational paraphernalia and facilities, classrooms, teaching aids, library, textbooks, teachers, organizational structure of the educational institutions showed very little change. The entire form and structure of the educational system remained as inadequate and as ill-prepared to achieve targets as it was when the country started its educational journey.

The number of schools, the enrollments, the teachers and the student population multiplied many times, but their function, quality, and level of performance remained the same as it was at the beginning. The features, which were characteristics of Pakistan and of our social, political and economic life, kept education at a very low priority level resulting in an utter failure to be able to achieve universal literacy and primary education. Meaningless and aimless education without a sense of direction, politicization of education, very low quality of educational performance and a very weak relationship with the national economy still afflicted education. The system continued to be stratified and class ridden with too 
much bureaucratic interference and control, restricting the educational opportunity and privileges for the elite classes. A very low level of government commitment to education, absence of a sound scientific and technical base never allowed to the system of education to move in the direction of people and masses in the country.

There were achievements also. The number of schools had increased. The universities multiplied, the enrollments increased many times. Yet on the whole, we had at the turn of century a system of education which was not prepared and ready to cater to the educational needs of the country. What can be a true yardstick is to compare Pakistan's progress with other developing countries, especially, countries in this region and South East Asia. Pakistan could only be seen as a straggler in the race with a very poor track record in a competitive perspective.

In brief, Pakistan entered the 21st century with hope and lots of good intentions, but with very little preparation. The emerging features of the new century could be seen with reasonable clarity at the close of the last century. The new century was going to be a century of rapid technological change with computers and information technology at the center stage. The proliferation of technology with the explosive expansion of knowledge would continue to accelerate its pace. The development and popular acceptability of market economy would spread its grip all over the globe and there would be a thrust in favor of privatization of industrial and business enterprises. The process of globalization would pick up speed and multinationals would spread a network binding all the countries together with the process of production. Of course, the system of industrially advanced countries and industrially dependent countries would continue and similarly political power would be unevenly distributed among the countries all over the world. As a developing country, Pakistan would have to play the role of a dependent region in the midst of innumerable problems and handicaps.

There was a political change at the end of the century and again the functioning government was ousted and the reins of power taken over by the Army. This time the critical issue was the continuing problem of power sharing between the elected government and the Army. Though, through the machinations and cooperation of the Army, the Muslim League, with Nawaz Sharif as its prominent leader, got himself elected with such a heavy margin as to fill the leader with a brimming confidence. This made somewhat more difficult for him to come to terms with the Pakistan army chief. The two-way tension combined with a series of political fluctuations, eventually culminating in the take over by the Army, with Gen. Pervez Musharraf as new leader. On the front of education the only contribution Nawaz Sharif was able to make was to announce a new education policy in 1998, a part of which is still being adhered to by the name of Education Sector Reform, now with the addition of the word 'President's' (PESR).

The scenario in which Pervez Musharraf assumed the responsibility of the government could not be more inhospitable than it was at the time of his take over. The international situation was certainly different but the national situation was even more so and carried the possibility of even getting worse. The trouble of Pakistan started with Afghanistan during the days of Gen. Zia-ul-Haque. Gradually the situation became worse and eventually culminated in the supremacy of the Taliban. The only possible element that could be looked on with favor was that at inception it was a friendly government to Pakistan but with full 
potential of friends becoming troublesome at any time. The Talibans were educationally brought up in the madressas of Pakistan and imbibed the peculiar features of the madressa environment. The conservative segment which was ever present in the body politic of Pakistan gradually became strong as a political lobby. This was a change from their previous political standing in Pakistan. Madressa educated clerics had some influence over the common people but were until now without a popular base and had never been able to get electoral support. The general impression among the mainstream educated city population had been that they were the conservative element of the society, busy making themselves more and more outdated. They would continue to stay at the periphery and would never be able to enjoy a respectable place in the mainstream of Pakistani society.

The political success of the Taliban in Afghanistan gave the madressa population their first boost and confidence and they began to see their relevance even in Pakistan's modern context. It was a reaffirmation of their persistent conviction that once they had access to political power they could set every thing right to create an Islamic state in the country. The rise of Taliban in Afghanistan gave an enormous impetus to different Islamic sectarian groups to step up their mutually exclusive claims. The upsurge of conservatism in the country started generating problems and troubles for the government and administration. The Kashmir dispute with India instigated the conservative elements even further and their armed cadres carried on their activities, in the name of Jehad, across the Indian held territory of Kashmir. The government was facing a dilemma as it was not in a position to stop these religious group incursions into Kashmir. The liberation of Kashmir was also a commitment it firmly believed in. The efforts were made to come to terms with India but India's tenacity not to budge from its political stand made any compromise unthinkable. The confidence of the religious groups, including the Talibans, continued to increase, stepping up of violent and hostile activities inside Kashmir were eventually begun to be seen by the western countries as terrorist activities.

The historic event of September 11, 2001 brought the matters to a head both in Iraq and Afghanistan. Talibans were chased out of Afghanistan by the US and European forces with the consent of Pakistan. The policy adopted by Pervez Musharraf was a Hobson's choice and was acquiesced to save Pakistan from the impending position of total destruction. Once the choice was made, it caused to generate problems inside the country and even from the organizations operating outside Pakistan with the active support from the Talibans. The political situation continues to be in a state of flux in the direction of worsening every day and nothing hopeful can be predicted for the future.

A concluding update of the running educational scene will not be out of place here. In the years of Musharraf's rule, despite a turbulent environment, the country was not without a semblance of political stability. The situation somewhat positively influenced the developmental scene in the country. The main agenda of his government on the external front was partnership with the US against terrorism. The other notable foreign policy shift was an opening up with India to improve relationship at all levels, a gesture which received paramount attention. The economic and financial indicators testify an overall improvement. The foreign exchange reserves increased from 1.6 billion to 12 billion according to figures available for the period 1999-2003. Tax revenues also registered an increase from 391 billion to 510 billion rupees in the same period. The national and external debt ratio 
has fallen but poverty reduction in the country is yet to register a decrease. This shows a failure at filtering the benefit to the poor. The overall rate of economic growth was on the rise consistently and reached a level of $6.6 \%$. Considerable outlays were specified for infrastructure development all over the country, especially, the cities. Defence industry received an impetus, a port city at Gawader was constructed and development of mega projects like the construction of dams were planned and partly implemented.

The impelling desire to make the country an economic success brought a concomitant change in the outlook about education. In addition to a social sector dispensation, interest augmented in seeing education as a development activity, an investment to build up human capital to sustain economic growth. This implied an ascent in the priority status of education. Concurrently focusing of attention on expansion and improvement of education in terms of quantity and quality begun to receive attention. The government showed an avowed interest in education and has never hesitated to present education as a national commitment. During the last several years education has received much more attention than has been the practice uptil now. The most noticeable step of the government has been a significant financial contribution to educational development activity, doubling the amount previously specified for the sector. From year 2000-05 percentage of GDP has marginally increased taking it from $1.8 \%$ to $2.1 \%$. In the increased percentage, the share of recurring allocation was $16 \%$ in $2004-05$, but the development allocation showed an increase of $110 \%$. Recently, a declaration has been made to increase the share of education in the GNP at the level of 4\%, a long aspired target set by UNESCO. This, perhaps, does not still match the percentage of GNP in neighboring countries in the South Asian region but in the context of Pakistan the increase should be seen as a quantum jump. This may give a convincing ring to the claim that the government is serious about education. It is a different matter that the dramatic jump is likely to give rise to issues of capacity and corruption. In these financial allocations external development assistance should also feature significantly as extra funding amounting to a commitment of 1.5 billion US dollars during the span of 2001-10. External funds come from a host of world countries with World Bank as a major donor.

Signs of a changed outlook on education are most notable in the field of higher education where the former University Grants Commission (UGC) was supplanted by a new Higher Education Commission (HEC). The new setup had a dynamic leadership and took up on itself to revamp and restructure the entire system of higher education making it more efficient and aligned with the international quality parameters. Half or $50 \%$ of the federal budgetary allocation for education went to HEC which is the channel to disburse money to public sector universities. The amount of money to be disbursed through HEC to public sector universities has been doubled. The target is to produce technical and professional human resource at a fast pace. Part of this aspiration must have come from the neighboring India which is commendably quoted to have made enormous educational development in the field of information and new technologies. During the period 2001-02 to 200405 universities were added. There was a planned effort to institute seven high standard technical universities with the help of foreign countries. In addition, the Commission has taken up the quality improvement of universities as a challenge and is paying vigorous attention to faculty development, pursuit of academic excellence and improving access to 
higher education. A structural change has also been introduced in making baccalaureate a four year program rather than the existing two year degree. The overall effort is to make higher education more responsive to developmental sector of the economy. The access target is a doubling of university enrollment in the next five years by increasing the capacity of the higher education institutions and also establishing new ones. Production of technical and professional human resources at a fast pace is in focus. The vision is to increase developing and recurring budgets for the higher education sector by $50 \%$ each year till the allocation reaches to $1 \%$ of GNP.

At the base level of the system of education, literacy is still a problem to grapple with. The adult literacy rate is $53 \%$ in Pakistan as against $61 \%$ in India. The target was to reach $80 \%$ literacy till 2015 , but with only a $2 \%$ per annum increase, the challenge was not met. Literacy figures in the country also show an imbalance and discrepancy between male/female, rural/urban segments and from province to province. At the provincial level Sindh shows the highest literacy rates of $55 \%$ and Balochistan lowest, at $37 \%$. Adult literacy for female in 2001-02 was $32 \%$ and made a gain of $8 \%$ to reach $40 \%$ in 200405. For the same period male literacy rate showed an increase from $58 \%$ to $65 \%$. Urban literacy remains higher at $71 \%$, whereas rural literacy rate shows a rate of $44 \%$. In absolute terms, the number of illiterates in $10+$ age group is 51.8 million. Literacy will continue to be a challenge and the hope of reaching a 100\% literacy rate by 2015 proved to be over-optimistic.

Next comes the schooling of children from primary to middle and secondary level. Nearly one half of children reaching the school going age still stay out of school and the country is not yet in a position to make schooling opportunity available to each and every child. By being signatory to Dakar World Education Forum 2007 and the millennium development goals, Pakistan had a commitment to attain universal primary education by 2015. This is a big bite to swallow. Pakistan has had to shift the earlier committed targets a number of times for universal primary education. The two indicators, the gross environment rate and net environment rate (NER) can be checked to see the progress made in the direction during the period under reference. The statistics available for the years from 2001-02 shows 14 percentage points increase in the gross primary enrollment which is more than 3 percentage per annum increase an average. Pakistan seems to have made sound progress in net enrolment rate at the primary level which increased by 10 percentage point from $42 \%$ in $2001-02$ to $52 \%$ in $2004-05$. In both the cases the acceleration is somewhat behind the anticipate a target but it is much better than the situation prior to Musharraf. The net education rate (NER) indicates the retention rate of children who complete the five years of primary school. The dropout has been a serious problem at this level of education, specially, in the rural setting. The increase in the NER indicates a decrease in the dropout rate which speaks well of the objective of the universal primary education. The need is to make primary education more functional, which can be done by providing facilities and by making the school environment more conducive to learning. The other problem keenly felt at the primary level of education is the gender gap, which has persisted at all school levels. The expectation has been to reduce it by $10 \%$ each year but the performance has been somewhat below the expectation level. The enrolment at the primary level in the private sector schools has shown an increase in recent years 
which testifies to the dissatisfaction of parents from low quality schooling in government sector. Middle level GER (age 10-12 years) has increased from $41 \%$ in 2001-02 to $46 \%$ in 2004-05. This achievement is far below the target of 55\% (Living Standards Measurement Survey, 2004). At the matric level GER is at $44 \%$ and NER is $11 \%$ with wider gender gaps. Under the devolution plan the government has now devolved this tier of education to the district governments and they now have the main responsibility of management financial support and improvement both output and quality. With the target in mind a revision of and revamping of curricula has been undertaken from Class-I to Class-XII with a focus on weeding out the excesses introduced in the name of Islamization during the Zia-ul-Haque days. Similarly, the text books of social studies and Pakistan studies have been revised so that the one sided interpretation of historical events can be avoided and the text books can reflect objectivity, especially in the context of India-Pakistan relationship.

Another feature of his policy of enlightenment is an envisioned madressa education reform. The project with name of Madressa Reforms was launched in 2002-03 with a capital cost of Rs.5759.395 million. The objective of the program has been to provide financial assistance to Deeni Madressas to introduce formal subjects in their curricula. This appears to be an almost first time effort to bring Madressa education closer to the mainstream system.

Despite the increase in expenditure on education in the public sector, educational opportunity in the country cannot be expanded without the assistance from the private sector. It is clear that the government for a considerable length of time in the coming years will not be able to build up educational facilities commensurate to the rate of increase in population, especially in the urban centers. The commitment of Prime Minister, Zulfiqar Ali Bhutto to nationalize education proved counter productive, but it gave a set back to the participation of the private sector which significantly discouraged investment in education sector. From the 1980's, however, there is a steady acceleration of interest in education by the private sector. The deterioration of academic standards in government schools and public universities has increased the need of private sector institutions as they must place an emphasis on quality education. Over the past decade, the government has increasingly acknowledged the importance of the contribution of the private sector and has recommended benchmark for opening of new private institutes and universities. What is, however, needed is that there should be a clear distinction between public spirited and commercially motivated private sector educational institutions. But these institutions also should not be without the vigil of the government and a supportive ownership of public spirited private institutions. In the private sector, there is also in the offing, a revival of the concept and practice of public/private partnership, which was in vogue prior to nationalization of educational institutions. Starting in mid 1990s, a major shift has occurred in the government approach to encourage and mobilize the private sector and civil society organizations in the financing management and delivery of education service including incentives for public/private partnerships to flourish for the promotion and improvement of education. It appears that the government is serious to include various other stakeholders in the delivery of education.

In brief, during the seven year period under discussion education has responded reasonably well to the demands of globalization and the market economy. There is an increasing 
consciousness about the need for quality education and to look at education as an instrument to produce human resources in the country. But the challenge is awesome and needs financial inputs and planning. The existing system is mired in corruption. An outdated bureaucratic setup has not allowed professionalism to grow and has given education the notoriety of a badly administered and most corrupt department, specially, at the provincial and district level. Complaints abound about lack of planning adhocism, and haphazard action without systematic monitoring or addressing the sustainability Issues. The ailments indicated have persisted for a very long time and though still present, should not be seen as inevitable.

\section{Conclusion}

As a final sum up education in the country in its sixty years journey has remained virtually a hostage in the grip of unstable political and unpredictable economic forces. The sustainability of the educational process has time and again been disrupted by the change of governments and by the failure of the country to give strength to a democratic process. Now once again the dark clouds are gathering.

Education, as we know, has never been a national priority and never had a respite to run its course. No doubt, perhaps, under the impelling globalization and market forces, and also because this sector has remained neglected so long, education in the recent past had the appearance of ascending the list of national priorities, but at this stage the only safe prediction, if at all, can be that the climate of hope for a long time to come will remain in the educational arena subject to the vagaries of political weather and the uncertainties of an easily shakable economy. 


\section{References}

Living Standards Measurement Survey. (2004). Living Standards Measurement (PSLM). Qazi, W., Raza, S. A., \& Jawaid, S. T. (2014). Higher education and growth performance of Pakistan: evidence from multivariate framework. Quality $\&$ Quantity, 48(3), $1651-1665$. 